\title{
Analysis of Student Developmental Tasks and Teacher Counselors Performance: A Preliminary Study
}

\author{
Fathur Rahman* \\ Guidance and Counseling Department \\ Universitas Negeri Yogyakarta \\ Yogyakarta, Indonesia \\ fathur@uny.ac.id*
}

\begin{abstract}
The research objectives are identifying the level of students developmental tasks and evaluating the performance of teacher counselors in managing school guidance and counseling program. Special region of Yogyakarta (DIY) was chosen as the primary research setting that includes 4 high school and teacher counselor working groups (MGBK) at 5 districts in DIY. This study involves the active participation of teacher counselors and students as well. Quantitative data obtained from the Developmental Task Inventory-Based Computer and it has been analyzed by descriptive statistics, while qualitative data obtained from interview analyzed by flow and interactive models. The conclusions are 1) the psychological development profile of students in several research locations has not meet the ideal criteria. Their development stage were still limited at the stage of "Conscious self" (suitable only for secondary students) and 2) the performance of teacher counselor can be concluded to be still relatively low by some indicators; no comprehensive planning and not based on assessment needs, illogical design, less structured, and unsupported environment socially.
\end{abstract}

Keywords - developmental tasks, teacher counselor performance

\section{INTRODUCTION}

The approach and purpose of guidance and counseling services are basically not only related to deviant behavior (maladaptive behavior) and how to prevent these behavioral aberrations, but also deal with the development of effective behavior [1, 2, 3]. This developmental perspective has broad implications that the development of healthy and effective behavior must be achieved by each individual in the context of their respective environments. Thus, guidance and counseling should need to be directed at efforts to facilitate individuals to become more aware of themselves, skilled in responding to the environment, and able to develop themselves into individuals who are meaningful and futureoriented $[1,2]$. Today, a counselor is expected to provide comprehensive, balanced, development-based school counseling program that target social and emotional supportive services, educational and academic planning, and vocational education for all students [4].

Development as a process and purpose of guidance and counseling can only occur effectively in interactions and healthy transactions between students and their environment. The nature of this approach lies in how individuals relate to their environment and how the reciprocal relationship between the two. This approach places individuals as part and one unit of systems and subsystems that cannot be separated. The focus of a centralized intervention on individuals alone does not have a significant impact on one's self-change. Therefore, the demand for developing counseling services for students in schools should not only focus on individuals (students) themselves, but also need to pay attention to changes in the environment of the students themselves.

The preliminary study in the context of developing the school guidance and counseling service model is based on objective conditions which show an ambiguity in the purpose of developing the psychological dimensions of students in schools, as well as the competency of guidance and counseling teachers who are incompetent in overcoming student problems. Based on several studies, it was revealed several facts about school counseling and guidance service activities which were actually counterproductive to student development. School guidance and counseling service activities that have developed in Indonesia have focused more on administrative and clerical activities [2], such as managing attendance and absence of students, imposing disciplinary sanctions on students who are late and deemed naughty. Thus, due to the problems, teacher counselor is stigmatized as a school police. The consequence of this reality, in the end led to the guidance and counseling services held in schools eventually encapsulated in traditional and clinical approaches.

The phenomena that occurs in schools in Indonesia are different in contrast to the development of guidance and counseling services in other countries. The counseling approach within the scope of education (schools) in several countries in the world has undergone a paradigmatic leap from clinical-based to development-oriented counseling services. The objectives achieved in this study consisted of 1) identifying students' self-development needs in several schools in DIY according to their development assumptions and psychological maturity; and 2) evaluating the performance of guidance and counseling teachers in several schools in DIY in implementing guidance and counseling services.

\section{METHODS}

This research is a part of three-year research series. Research conducted in the first year was located in 4 schools and 5 guidance and counseling teachers working group 
spread across five districts in the Special Region of Yogyakarta (DIY). The research subjects involved in the research in this first year were 325 high school students covering 5 districts in DIY Province. Subjects from 83 Yogyakarta Vocational Schools were 83 students, subjects from MAN Wonokromo, Bantul were 67 students, subjects from SMAN 1 Ngemplak, Sleman were 61 students, subjects from SMAN 1 Wates were 64 students, and subjects from SMAN 2 Wonosari, Gunungkidul were 50 students. Meanwhile, the number of teachers involved as interview respondents in this study was 5 persons.

Student development and teacher performance were collected using Developmental Task Inventory and interviews. Quantitative and qualitative analysis is used to describe the profile of student development and teacher performance. Analysis of student development tasks and teacher performance will be used as a reference in making developmental counseling modules.

\section{RESULTS AND DISCUSSION}

The identification of student's developmental tasks carried out in this study using a computerized Developmental Task Inventory which was developed by Sunaryo Kartadinata and colleagues at the Universitas Pendidikan Indonesia, Bandung. With these tools, the research team can understand precisely the level of student's developmental tasks individually or in groups, identify problems that hinder development and assist students who have problems completing their developmental tasks.

Inventory measures the level of student developmental tasks in 11 aspects, namely 1) foundation of religious life, 2) foundation of ethical behavior, 3) emotional maturity, 4) intellectual maturity, 5) awareness of responsibility, 6) social role as male or female, 7) selfacceptance and its development, 8) independence of economic behavior, 9) insight and career preparation, 10) maturity of relationships with peers, and 11) self preparation for marriage and family life.

The ideal expectations obtained from this inventory, students should ideally be able to reach the level of individuality. The level of individuality means that students are able to increase individuality awareness, aware of emotional conflict between independence and dependence, more tolerant of oneself and others, knowing the existence of individual differences, being able to distinguish internal life and external conditions, knowing the complexity of self, and caring about social problems.
Based on the table 1, the average score of the level of development of students from all schools studied reached 4.60 with an average consistency of answers of 7.11. The meaning of the results of this achievement means that on average all students have not reached the expected level of development, which is a score of 6 which means that all students are in the INDIVIDUALITY level. If we see a trend toward an average score of 4.60 , it means that all students are still limited to the SELF-CONSCIOUS level, which is limited to understanding and knowing oneself and has not yet reached the level of self-actualization that is expected to be fully in accordance with the ideal developmental tasks.

Profile of student development in several locations which is used as a unit of research analysis shows that the level of development of students has not reached the expected ideal level. As mentioned earlier, the stage of development of high school students should have reached the stage of individuality. The level of individuality means that in students there has been an increase in individuality awareness, aware of the emotional conflict between independence and dependence, more tolerant of oneself and others, recognizing the existence of individual differences, being able to distinguish internal life and external conditions, knowing self-complexity, and care about developmental and social problems.

The low level of development of these students further strengthens the thesis revealed by Myrick [5] that the developmental approach must be a top priority in the implementation of guidance and counseling services. One of the unachieved levels of individuality in the psychological development of students can be attributed to the accentuation of counseling and guidance programs in schools that emphasize the crisis and clinical approach, namely just waiting for problems without proactive efforts to seek prevention and optimization of developmental tasks.

Therefore, program design concerned with optimal student development is needed. The scope of the intended development should cover 11 aspects of development (as stated in the inventory). All aspects are in line with the developmental domain that includes career planning and exploration, self and social knowledge, and educational development [6].

Table 1. Developmental Task Profile of High School Students

\begin{tabular}{|c|l|c|c|c|c|}
\hline \multirow{2}{*}{ No } & \multicolumn{1}{|c|}{ Developmental Aspects } & \multicolumn{3}{c|}{ Developmental Index } \\
\cline { 3 - 6 } & & $\begin{array}{c}\text { SMKN 3 } \\
\text { Yogyakarta }\end{array}$ & $\begin{array}{c}\text { MAN } \\
\text { Wonokromo } \\
\text { Bantul }\end{array}$ & $\begin{array}{c}\text { SMAN 1 } \\
\text { Ngemplak }\end{array}$ & $\begin{array}{c}\text { SMAN 1 } \\
\text { Wates }\end{array}$ \\
\hline 1 & foundation of religious life & 4.67 & 4.64 & 4.67 & 4.74 \\
\hline 2 & foundation of ethical behavior & 4.58 & 4.57 & 4.7 & 4.79 \\
\hline 3 & emotional maturity & 4.64 & 4.57 & 4.49 & 4.64 \\
\hline 4 & intellectual maturity & 4.74 & 4.66 & 4.58 & 4.73 \\
\hline 5 & awareness of responsibility & 4.81 & 4.67 & 4.73 \\
\hline 6 & social role as male or female & 4.79 & 4.64 & 4.71 & 4.66 \\
\hline 7 & self-acceptance and its development & 4.71 & 4.75 & 4.8 \\
\hline 8 & independence of economic behavior & 4.74 & 4.74 & 4.71 \\
\hline 9 & insight and career preparation & 4.73 & 4.44 & 4.83 \\
\hline 10 & maturity of relationships with peers & 4.87 & 4.83 & 4.82 \\
\hline 11 & self preparation for marriage and family life & 4.67 & 4,63 & 4.69 \\
\hline & Mean of score & 4.72 & 4.23 & 4.71 & 4.94 \\
\hline
\end{tabular}


Interviewing to the teachers from SMAN 1 Wates and SMAN 1 Ngemplak, Sleman was conducted in the form of directed interviews which developed from the counselor performance evaluation list [7]. The results of interviews to the teachers can be seen in the following table.

Table 2. Teacher Counselor's Performance

\begin{tabular}{|c|c|c|}
\hline NO & DIMENSION & RESULTS \\
\hline 1 & $\begin{array}{l}\text { needs analysis of } \\
\text { guidance and } \\
\text { counseling } \\
\text { services }\end{array}$ & $\begin{array}{l}4 \text { of the } 5 \text { guidance and counseling } \\
\text { teachers did not assess the needs of } \\
\text { various aspects needed in the guidance and } \\
\text { counseling program planning }\end{array}$ \\
\hline 2 & $\begin{array}{l}\text { ability to } \\
\text { implementing } \\
\text { guidance } \\
\text { curriculum } \\
\text { activities }\end{array}$ & $\begin{array}{l}4 \text { of } 5 \text { teachers do not conduct guidance } \\
\text { curriculum activities because there is no } \\
\text { time available. Teachers who implement } \\
\text { the guidance curriculum feel unsatisfied } \\
\text { with the material and methods used }\end{array}$ \\
\hline 3 & $\begin{array}{l}\text { Ability to } \\
\text { implementing } \\
\text { responsive } \\
\text { service }\end{array}$ & $\begin{array}{l}\text { All teachers feel underestimate to the } \\
\text { individual and group counseling activities } \\
\text { that have been implemented. The low } \\
\text { rating is indicated by the following: } \\
\text { a. not yet mastered maximum } \\
\text { counseling skills } \\
\text { b. more busy with administrative tasks } \\
\text { from school managers } \\
\text { c. problem analysis and the solution is } \\
\text { still not effective }\end{array}$ \\
\hline 4 & $\begin{array}{l}\text { Ability to } \\
\text { implementing } \\
\text { individual } \\
\text { planning service }\end{array}$ & $\begin{array}{l}\text { a. some teachers do not understand what } \\
\text { and how it is intended and the } \\
\text { implementation of individual planning } \\
\text { services } \\
\text { b. This activity is not satisfactory } \\
\text { because it is often confused to help } \\
\text { because there is no set of data about } \\
\text { the problems and needs of students }\end{array}$ \\
\hline 5 & $\begin{array}{l}\text { Ability to } \\
\text { organize system } \\
\text { support }\end{array}$ & $\begin{array}{l}\text { a. Feeling unsatisfactory because the } \\
\text { teacher has not been able to involve } \\
\text { parental participation in developing } \\
\text { effective student behavior } \\
\text { b. collaborative activities do not occur at } \\
\text { all because of negative perceptions of } \\
\text { guidance and counseling services }\end{array}$ \\
\hline
\end{tabular}

The findings obtained from interviews showed the huge problem related to the unclear performance of the guidance and counseling teachers and the low quality of guidance and counseling in schools. Some of the problems that arise, among others, are the absence of needs and problems assessment as a basis for planning guidance and counseling programs, the various components of BK services that are not implemented in a balanced and maximum manner. This condition is in line with the findings of Sunaryo Kartadinata [2] that guidance and counseling services are limited to formal needs rather than as actual needs.

Not infrequently guidance and counseling services are only administrative jobs that strongly emphasize physical evidence rather than a professional job that emphasizes the process of developing behavior using effective psychological interventions. Guidance and counseling services in schools still require more administrative and clerical work rather than professional services to improve student welfare and better performance.
Other findings from this study also indicate the low support of the social environment needed by students in overcoming the problems of everyday life. This reality is different from experts explanation $[3,8,9,10]$ that development-oriented counseling models are very concerned about the student's development environment that influences to the students behavior. The guidance and counseling program should be directed to the development of external assets consisting of; social support, empowerment, self-hope and environmental boundaries, opportunity support.

\section{CONCLUSION}

Based on the research that has been done, the conclusions that can be drawn are as follows; a) Profile of the development of high school students in several research locations shows the level of development that has not met the ideal criteria in the individuality stage. The development of high school students who are the subject of research is still limited to the Self-Awareness stage (suitable only for secondary students); and b). The performance teacher counselor and the quality of the guidance and counseling program can be said to be relatively low with several indications, namely planning that is not comprehensive and not based on assessment of needs and problems, illogical and unstructured design, and low- involvement of developmental environment around students, such us family and society.

\section{REFERENCES}

[1] Kartadinata, S. (1999). Quality Improvement and Management System Development of School Guidance and Counseling Services, the Journal of Education, Vol. 6, December, 1999.

[2] Kartadinata, S. (2003). Bimbingan dan Konseling Perkembangan; Pendekatan Alternatif Bagi Perbaikan Mutu dan Sistem Manajemen Layanan Bimbingan dan Konseling Sekolah. Jurnal Bimbingan dan Konseling, Vol. VI/11 Mei 2003.

[3] Galassi, J. P. \& Akos, P. (2004). Developmental Advocacy: TwentyFirst Century School Counseling, Journal of Counseling and Development, Vol. 82, 2004, p. 146-157.

[4] Morgan, L. W., Greenwaldt, M. E. \& Gosseling, K. P. (2014). School Counselors' Perception of Competency in Career Counseling. The Professional Counselor, 4 (5)., p. 481-496. http://tpcjournal.nbcc.org.

[5] Muro, J. J. \& Kottman, T. (1995). Guidance and Counseling in Elementery School and Middle School., Iowa: Brown and Benchmark Publisher.

[6] Sciarra, D. T. (2004). School Counseling; Foundation and Contemporary Issues. Belmont USA: Brooks/Cole-Thomson Learning.

[7] Gysbers \& Henderson (2012). Developing \& Managing Your School Guidance Counseling Program. Fifth Edition. American Counseling Association.

[8] Myer, J. F., Shoffner, M. F., \& Briggs, M. K. (2002). Developmental Counseling and Therapy; An effective approach to Understanding and Counseling Children. Professional School Counseling, 5/3, p. 194213.

[9] Toporek, R. L. (2006). Progress Toward Creating a Common Language and Framework for Understanding Advocacy in Counseling, Counseling and Human Development Journal, 38/9. p. 16.

[10] Milsom, A. \& Bryant, J. (2006). School Counseling Departmental Web Sites; What Message Do We Send? Professional School Counseling, 10/2, p. 210-216. 